\title{
Accounting
}

\section{A longitudinal study of self-selection, learning-by-exporting and core-competence: The case of small- and medium- sized enterprises in Vietnam}

\section{Pham Thi Huyen Tranga and Hoang Nam $\mathrm{Vu}^{\mathrm{a}^{*}}$}

\begin{tabular}{|c|}
\hline CHRON I C L E \\
\hline $\begin{array}{l}\text { Article history: } \\
\text { Received March } 222020 \\
\text { Received in revised format March } \\
302020 \\
\text { Accepted April } 142020 \\
\text { Available online } \\
\text { April } 142020\end{array}$ \\
\hline $\begin{array}{l}\text { Keywords: } \\
\text { Self-selection } \\
\text { Learning-by-exporting } \\
\text { Core competency } \\
\text { SMEs } \\
\text { Vietnam }\end{array}$ \\
\hline
\end{tabular}

\section{A B S T R A C T}

Based on longitudinal data from biennial surveys of small- and medium- sized enterprises (SMEs) in Vietnam conducted from 2007 to 2013, we find supports to the self-selection and learning-by-exporting hypotheses. We find that the SMEs having higher sunk costs and capital size are more likely to become exporters. Applying the propensity score matching method in combination with the Difference-inDifference estimation, the study finds that export has raised SMEs' productivity measured by either TFP or labor productivity, sales revenue, and value added of the SMEs. Furthermore, the gains from learning-by-exporting and specializing in core-competence products were stronger in the early years of entry into the export markets. These findings suggest policies to promote export of SMEs in an appropriate timing.

\section{Introduction}

As firms grow in increasingly limited domestic markets, they will export their products. Understanding what factors determine firms' export behavior is important. Indeed, a large body of literature has provided insights into various determinants of firms' export behaviors, which are both internal and external to firms (Monreal-Pérez et al., 2012; Vu et al., 2013; Wagner 2007, 2012). These studies highlighted key internal factors including innovation and productivity of a firm in affecting its export. Nevertheless, other studies found no evidence of firms self-selecting into the foreign markets (Bernard \& Jensen, 2004; Castellani, 2002; Greenaway \& Kneller, 2004; Par \& Nan, 2004). In addition, existing studies have confirmed a learning-byexporting process of exporting firms. While exporting, firms accumulate and benefit from accumulated knowledge. As a result, firms are able to improve their development processes through intensified innovation (Alegre \& Chiva, 2008; Hitt et al., 1997). Thus, innovative capacity of firms plays an important necessary condition to realize potential learning opportunities through exporting. Nevertheless, the learning-by-exporting hypothesis has been rejected in certain cases (Bernard \& Jensen, 2004b; Monreal-Pérez et al., 2012) or shown to be conditional upon a number of factors such as direction of export (Silva et al., 2010), firm ownership (Park, 2011) and degree of internationalization (Kafouros et al., 2008). 
Previous studies have, however, paid little attention to export behaviors of small firms, which are characterized by weak capacity of innovation, low productivity, and limited internationalization (Vu \& Hoang, 2019; Monreal-Pérez et al., 2012). Moreover, in transition economies like Vietnam, it is important for scholars to test the self-selection and learning-by-exporting hypotheses in a unique development context. The economic reform, which started in 1986, has transformed Vietnam from a centrally planned economy to a market-oriented one and resulted in remarkable achievement in economic development. The transformation of the economy has been greatly supported by the export-led-growth policies (General Statistics Office, 2017). During the last two decades, while the average economic growth rate has been $6.5 \%$ per year, export has grown at an average rate of $18.8 \%$ per year (General Statistics Office, 2017). While rapid export growth has been observed for foreign invested firms, domestic firms, which are dominated by the number of small- and medium- sized enterprises (SMEs), have faced with large trade deficit. In fact, only $20 \%$ of the SMEs have involved in exporting activities (VCCI, 2017). These facts have provided an ideal context to test the hypotheses mentioned above. Based on longitudinal data from biennial surveys of SMEs in Vietnam conducted from 2005 to 2013, we confirm the self-selection and learning-by-exporting hypotheses for the SMEs in Vietnam as having been indicated in existing studies (Wagner, 2007; Monreal-Pérez et al., 2012). We find that the SMEs having incurred higher sunk costs of entering export markets, having larger capital size and more labor-intensive products are more likely to become exporters. Applying the propensity score matching method in combination with the Difference-in-Difference estimation, the study finds that export has raised SMEs' productivity, which is measured by either TFP or labor productivity. In addition, export has positive effects on sales revenue and value added of the SMEs. The gains from learning-by-exporting and specializing in corecompetence products were stronger in the early years of entry into the export markets.

The remaining of the paper is structured as follows. The next section presents literature review on the hypotheses of self-selection and learning-by-exporting. The third section describes methodology and data. Section 4 provides empirical results and discusses the findings. Conclusion is presented in Section 5.

\section{Literature review and hypotheses}

\subsection{Self-selection hypothesis}

The literature on the relationship between export and firm performance, which is often measured by firm productivity or innovation, has been revitalized since the study by Melitz (2003). Different from traditional trade models that assume identical firms, the break-through Melitz's idea, which employs a heterogeneous firm model, has set an important theoretical framework for what is called the New New Trade theory. Trade induces more productive firms to penetrate foreign markets and force less efficient ones to produce only for the domestic market or even to exit. The reallocation of resources towards better performing firms explains for an increase in aggregate productivity of the industry. Self-selection hypothesis means that the more productive or more innovative firms self-select to become exporters. More productive or more innovative firms will export because there are additional costs of exporting such as transportation costs and distribution or marketing costs. These costs act as an entry barrier that less productive and less innovative firms cannot overcome. From the firms' perspective, desire to export tomorrow forces them to improve productivity and innovation today so that they become competitive in foreign markets. As a result, any current differences between exporters and non-exporters may be partly explained by their ex ante differences. The framework proposed by Melitz (2003) has triggered a series of empirical works on testing the causal relationship between productivity and export of firms, indicating the heterogeneity of resources in both developed and developing countries (Wernerfelt, 1984; Fornes \& Cardoza, 2019; Feng et al., 2019; Doan et al., 2020). Various indicators to measure productivity and factors affecting productivity of firms have been used to examine the self-selection hypothesis (Alvarez \& Lopez, 2005; Arnold \& Hussinger, 2005; Aw et al., 2001; Bernard \& Jensen, 1995, 1999, 2004; Clerides et al., 1998; Delgado et al., 2002; Greenaway \& Kneller, 2004; Par \& Nan, 2004). Another strand of studies finds strong causality running from firms' innovative activities to their export (Leonidou et al., 2007; Pla-Barber \& Alegre, 2007; Filipescu et al., 2009; Monreal-Pérez et al., 2012). These studies agree that innovation enhances competitiveness and differentiates firms in the export markets. As Vietnam is in the transition period from a centrally planned economy to a market-oriented one, the number of export firms is limited. The export firms are more productive and carry out more innovative activities than others (Ministry of Planning and Investment, 2016). As a result, we would like to test the following hypothesis.

\section{H1: The small-and-medium sized enterprises with higher sunk costs, productivity and larger size are more likely to export.}

\subsection{Learning-by-exporting hypothesis}

Learning-by-exporting hypothesis is about the relationship between firm export and firm performance. Clerides et al. (1998) establish that after joining the export markets firms improve their performance efficiency, which is measured by productivity, by acquiring knowledge, information, and experience from the foreign markets. Exporting firms can utilize their production to reduce costs and increase efficiency. To penetrate foreign markets with new customers, new quality standards, new technology, firms are forced to innovate by creating new products and applying new production processes. Additionally, to survive more 
intense competition from foreign competitors firms have to boost their productivity. Benefits to exporting firms may also come from integration into the global network. The fact that firms benefit from knowledge learning, technological diffusion, and increasing efficiency upon exporting their goods and services is referred to as the hypothesis of learning-by-exporting.

Empirical studies for the learning-by-exporting hypothesis are mixed. Martins \& Yang (2009) conducted a meta-analysis on 30 studies that tested the learning-by-exporting hypothesis and find that learning effects are higher in developing countries than in developed counterparts. The argument is that the products exported from the former to the latter have higher quality than those sold domestically. As a result, exporters have to innovate more to meet high-quality standard in developed countries. Wagner (2012) agrees that the impact of export on productivity is stronger in developing countries, where there is a small number of exporters and the level of international integration is low. Other existing studies also supported this hypothesis (Girma et al., 2004; Greenaway \& Kneller, 2004; Kimura \& Kiyota, 2006; Baldwin \& Gu, 2003; A. Park et al., 2010; Fernandes \& Isgut, 2015). Nevertheless, other studies found weak evidence to support the learning-by-exporting hypothesis (Bernard \& Jensen, 1995, 1999; Arnold \& Hussinger, 2005; Castellani, 2002; Par \& Nan, 2004). Castellani (2002) argues that an average Italian manufacturing exporter does not have faster productivity growth. It is export intensity that determines how firm productivity grows through exporting. Findings from Par \& Nan (2004) are in agreement with Castellani (2002). Other studies also found no evidence of learning effects after the penetration of firms in foreign markets (Bernard \& Jensen, 1995, 1999; Arnold \& Hussinger, 2005). The SMEs in Vietnam have been increasingly exposed to export and foreign markets since the last three decades (Ministry of Planning and Investment, 2016). Whether they have benefited from learning-by-exporting is worth investigating. Thus, we would like to test the following hypothesis.

H2: Small-and medium-sized enterprises in Vietnam have become more productive after exporting their goods.

\subsection{Core competence hypothesis}

The relationship between firms' export and productivity can be also explained by the core competence hypothesis. According to this hypothesis, exporters optimize their product scope to specialize in their core competence (Feenstra \& Ma, 2007; Eckel \& Neary, 2010; Bernard et al., 2011). To survive competition from foreign markets, exporting firms need to specialize in what they do the best by dropping less productive product lines. This within-firm reallocation of resources across products increases firm productivity and raises average productivity of the industry (Bernard et al., 2011; Ma et al., 2014).

Since the resource reallocation is found within firms, standard theories of trade that emphasize between-sector reallocation of resources cannot be used to explain within-industry heterogeneity in factor intensity. While many studies confirm the existence of self-selection and mixed evidence for the learning-by-exporting effects, researchers are relatively silent about the core competence hypothesis. In this study, we would like to test the following hypothesis.

H3: Exporting small-and medium-sized enterprises in Vietnam have become more focused on their core competence.

\section{Methodology and data}

\subsection{Methodology}

\subsubsection{Self-selection estimation}

Previous studies including Baldwin (1988), Baldwin \& Krugman (1989), and Dixit (1989) have laid out a basis for a model of firms' decision to export. They introduced sunk costs that firms will incur when they enter foreign markets. These sunk costs include entry costs such as expenses to study new markets, to adjust current products, or to establish distribution channels. With entry costs, current production depends on the production in the previous periods. Roberts \& Tybout (1997) were the first to turn these assumptions into a model to explicitly address effects of entry and exit costs to the decision of export by firms. Mathematical expressions of this model are provided in Appendix A. Following the approach proposed by Roberts \& Tybout (1997) to use a non-structural binary choice model to estimate factors that affect firms' decision to export, which indicates the self-selection evidence, we applied the following empirical model:

$$
\text { Export }_{i t}=\beta_{0}+\beta_{1} \text { Export }_{i t-1}+\beta_{2} \text { Productivity }_{i t-1}+\beta_{3} Z_{i t-1}+\varepsilon_{i t}
$$

where Export $_{i t}$ is the dependent variable representing export status of firm $i$ at time $t$. Export it $_{\text {e }}$ equals 1 if firm i exports at time $\mathrm{t}$ and 0 otherwise. On the right-hand side, to proxy for sunk costs lagged export Export $t_{i t-1}$ is included (Greenaway \& Kneller 2004). Productivity ${ }_{i t-1}$, which is the main variable of interest, is in the lagged form. The lagged productivity was used to test whether firm $i$ had been more productive before joining the export markets. $Z_{i t-1}$ is a vector of firm i's characteristics. These variables are in the lagged form to avoid possible endogenous problems. In this study, we used labor productivity, which is measured by total value added divided by total regular workforce, and total factor productivity (TFP), which was estimated following Levinsohn \& Petrin (2003), in our estimation to check for the robustness. Following Wagner (2007), we used firm size and firm age to estimate firms' decision to export. Firm size is found by Wagner (2007) to have a positive effect on a firm's export. In this study, we used total physical capital to represent firm size. Firm age, which is measured by number of years since 
establishment, is another determinant of export as firms that have longer time staying in businesses are more experienced, acquire more capital and knowledge, and have better relationships with foreign partners and, thus, have better chances of being exporters (Greenaway \& Kneller 2004). Nevertheless, young firms might have higher probability to export (Alvarez \& Lopez 2005). In Eq. (1), we also included capital intensity, which is measured by capital labor ratio, as another important factor determining export of firms. De Loeker (2007) and Ranjan \& Raychaudhuri (2011) find that a firm's capital intensity is positively correlated with its export status as a firm with higher capital intensity has higher level of technology, which generates competitiveness. Nonetheless, Ma et al. (2014) find that Chinese exporters were less capital intensity than non-exporters as they were mainly in the labor-intensive industries. Other firm characteristics including quality of labor, innovation, credit constraint, networking, government assistance, location, type of product, and ownership were also included in Equation 1. Following Bernard \& Jensen $(1999,2004)$ and De Loeker $(2007)$, we used average wage, which is a proxy for quality of labor, in our estimation. A dummy variable for innovation, which represents either introduction of new products or new production processes, was added to the model following Alvarez \& Lopez (2005) and Nguyen et al. (2008). A dummy variable for credit constraint taking the value of 1 if a firm applied but failed to get loans was used in the estimation as pointed out by Minetti \& Zhu (2011) and Feenstra et al. (2014). A dummy indicating a long-term relationship with foreign partners was also used since networking was found to affect firms' decision to export (Tomiura, 2007). A dummy for government support was used in our estimation. Finally, dummies for firm's location representing ten provinces in Vietnam, dummies for industry classification using ISIC 2digit level, and dummies for five types of ownership were included in our estimation. To deal with the problems of including lagged dependent variables as explanatory variables, an appropriate estimation method is to use the dynamic random Probit model developed by Heckman (1981). This estimation method corrects for a problem of missing unobservable factors that might have influence on the decision to export. According to Heckman (1981) a missing unobservable factor can be plantheterogeneity, which might cause the problem of initial conditions. For robustness check, an estimation utilizing a sub-sample of firms that do not switch their export status in all studying periods was employed to single out the effect of past experience or sunk costs.

\subsubsection{Learning-by-exporting estimation}

To estimate the learning-by-exporting effect, either export status or export intensity can be used as the explanatory variable. To control for potential simultaneous problems arising from bi-direction relationship between the dependent variable and the explanatory variable, we applied the matching methodology in combination with the Difference-in-Difference estimation. The matching process considers exporting as a treatment. The effects of exporting on firm performance were estimated by comparing performance of the exporting firms with the non-exporting firms, which are considered as the control group. Specifically, the following equation was estimated:

$$
E\left\{Y_{i t+s}^{1}-Y_{i t+s}^{0} \mid \text { Export }_{i t}=1\right\}=E\left\{Y_{i t+s}^{1} \mid \text { Export }_{i t}=1\right\}-E\left\{Y_{i t+s}^{0} \mid \text { Export }_{i t}=1\right\}
$$

where $Y_{i t+s}^{1}$ is the expected outcome when firm i exports at time $\mathrm{t}+\mathrm{s} ; Y_{i t+s}^{0}$ is the expected outcome when firm i had not exported at time $\mathrm{t}+\mathrm{s}$; Export $_{i t}$ is the export status of firm $i$ at the initial time $t$. Eq. (2) presents the average treatment on the treated (ATT), which reflects effects on the treated group caused by the treatment. In this study, that is the effect of exporting on performance of the exporters. If we compare the difference in performance of the treatment and control group, the results will be biased because the treatment is not randomly distributed as firms self-select to become exporters. As a result, we applied the propensity score matching technique (PSM) developed by Rosenbaum \& Robin (1983), which uses the probability score of being an exporter as the benchmark to match firms. For the non-exporting firms, we selected the control group of firms that are similar to the exporting firms. The best way to estimate the learning-by-exporting effect is to take the group of firms that have newly entered the export market during the study period into account. If Eq. (2) is used, a firm could have been exporting before the base time $t$. Therefore, the interpretation then would be estimating the probability of continuing being exporter rather than probability of entering export market. In addition, using Equation 2 would result in the problem of correlation between lagged export status and pre-entry characteristics such as productivity or firm size. Hence, to have better estimation of the learning-byexporting effect, Equation 2 was revised as follows:

$$
E\left\{Y_{i t+s}^{1}-Y_{i t+s}^{0} \mid \text { Newentry } y_{i t}=1\right\}=E\left\{Y_{i t+s}^{1} \mid \text { Newentry }_{i t}=1\right\}-E\left\{Y_{i t+s}^{0} \mid \text { Newentry } \text { it }=1\right\},
$$

where Newentry ${ }_{i}$ is a dummy variable which equals 1 if a firm starts entering the export market or re-entering the exporting market after two continuous periods without exporting. An assumption was that after two continues periods or four years firms had already paid nearly all new sunk costs in order to penetrate the export market; Export $_{i}$ is a dummy variable which equals 1 if a firm export. The key point is how to select a valid control group from the non-exporting firms. Comparison between treated firms and control firms could be based on characteristics that determine the entry decision such as productivity (TFP), firm size, capital intensity, wage, innovation, credit constraint, government support, industry and ownership (Greenaway et al., 2005). The propensity score of firm $i$ (pi) was estimated using the panel Probit random effect model as below: 

Government support $\mathrm{it}_{\mathrm{i}-1}$, Industry, Ownership).

After getting the estimated propensity score (pi), we used the matching option of nearest neighbor, which selects a nonexporting firm $j$ to match with new entrant firm $i$ that satisfies:

$$
\left|p_{i}-p_{j}\right|=\min _{l \in\{E X P=0\}}\left(p_{i}-p_{l}\right) \text {. }
$$

We implemented the matching procedure with the option of one-to-one nearest neighbor matching (Leuven \& Sianesi 2018) for every year to find valid control firms for each firm that newly enters the export market in that year. We also tested the balancing condition to ensure that the treated and control groups of firms are not systematically different prior to export entry (Becker \& Ichino 2002). Table 1 provides details about the number of matched firms that forms a panel data of 140 firms over four periods of time. In total, we had 560 observations.

\section{Table 1}

Number of matched firms (one-to-one nearest neighbor matching)

\begin{tabular}{|c|c|c|c|c|}
\hline Year & $\mathrm{t}$ & Treated firms & Control firms & Total \\
\hline 2007 & 0 & N/A & N/A & N/A \\
\hline 2009 & 1 & 37 & 35 & 72 \\
\hline 2011 & 2 & 13 & 13 & 26 \\
\hline 2013 & 3 & 21 & 21 & 42 \\
\hline Total & & 71 & 69 & 140 \\
\hline
\end{tabular}

We then applied the Difference-in-Difference method to estimate the ATT effects with the following function:

$$
\operatorname{LnY}_{i t}=\beta_{1} \text { treatment }_{i t}+\beta_{2} \text { post }_{i t}+\beta_{3} \text { treatment }_{i t} \times \text { post }_{i t}+D_{\text {ind }}+D_{\text {owenership }}+u_{i t}
$$

where $Y_{i t}$ is for firm performance measured by either TFP, labor productivity, sales revenue, or value added; Treatment $t_{i t}$ is a dummy variable that equals 1 if a firm is in the treatment group, and 0 otherwise; post $t_{i t}$ is a dummy variable that equals 1 if a firm starts exporting, 0 in the previous years, and 1 in the following years. The control firm has the same post values with its matched-firm. Coefficient $\beta 3$ reflects the ATT effect of export on performance. It can be estimated by the panel random-effects model with the control variables as having been mentioned above.

\subsubsection{Core Competence Estimation}

To test the core competence effect, we employed the matching method in combination with the Difference-in-Difference estimation as specified above. We used the change in capital intensity, which is measured by total physical capital, divided by the number of regular labor force to proxy for the resource reallocation across products within firms. We focused on the groups of new exporters and non-exporters. The following empirical estimation was applied to estimate the core-competence effect:

$$
\text { LnCap_Int }_{i t}=\beta_{1} \text { treatment }_{i t}+\beta_{2} \text { post }_{i t}+\beta_{3} \text { treatment }_{i t} \times \text { post }_{i t}+\text { Control }_{i t}+u_{i t}
$$

where LnCap_Int $t_{i t}$ is capital intensity in log form; Treatment $t_{i t}$ is equal 1 if it is a treated firm and 0 otherwise; Post $t_{i t}$ is a dummy variable taking value of 1 if a firm starts exporting, taking value of 0 in previous years and 1 in following years. The control firm has the same flow of post values as its matched treated firm. Coefficient $\beta_{3}$ reflects the ATT core-competence effect.

\subsection{Data}

Data for this study were from the SME surveys conducted in 2007, 2009, 2011, and 2013 by the Institute of Labor Science and Social Affairs (ILSSA) and the Central Institute for Economic Management (CIEM) with the technical support from Copenhagen University, Denmark. The data contain information of SMEs from 10 provinces spreading all over Vietnam about general characteristics of SMEs and their owners/managers, economic account, production, sales, costs, export, employment, investment, innovation, economic constraints, and support from the government. There were roughly 2,500 sampled SMEs in each round of the surveys. The majority of them have been repeatedly surveyed, which allowed us to create a balanced panel dataset. We singled out state-owned and foreign-owned SMEs, which accounted for less than $1 \%$ of the total number of the sampled SMEs. We, thus, came up with a balanced panel dataset of 1,359 repeated firms, which reported information biennially from 2007 to 2013. These SMEs operated in more than 20 industries according to the ISIC categories and concentrated in industries such as fabricated metal products, food and beverages, wood, furniture, rubber, textiles. Ownership types of the sampled SMEs included household enterprises, cooperative firms, private companies, limited companies, and joint stock 
companies. Household enterprises accounted for $72 \%$ the total number of the sampled SMEs. All values were in real term, which have been deflated to the 2010 values using the Vietnam GDP deflators provided by the World Bank (2019).

\section{Results and Discussion}

\subsection{Self-selection estimation results}

Estimation results for the self-selection are presented in Table 2, which contains eight simulations using Probit model in pooled regression, Random-effects Probit, Heckman's Random-effect dynamic model, and Probit model for a sub-sample of nonswitching status SMEs. In Regressions from (1) to (4), TFP was used to represent firm productivity, while labor productivity was used in Regressions from Eq. (5) to Eq. (8).

\section{Table 2}

Determinants of decision to export

\begin{tabular}{|c|c|c|c|c|c|c|c|c|}
\hline & $\begin{array}{c}\text { (1) } \\
\text { Probit }\end{array}$ & $\begin{array}{c}(2) \\
\text { RE } \\
\text { Probit }\end{array}$ & $\begin{array}{c}(3) \\
\text { RE dynamic } \\
\text { probit }\end{array}$ & $\begin{array}{c}\text { (4) } \\
\text { Sub-sample }\end{array}$ & $\begin{array}{l}(5) \\
\text { Probit }\end{array}$ & $\begin{array}{c}(6) \\
\text { RE } \\
\text { Probit }\end{array}$ & $\begin{array}{c}(7) \\
\text { RE dynamic } \\
\text { probit } \\
\end{array}$ & $\begin{array}{c}(8) \\
\text { Sub-sample }\end{array}$ \\
\hline Export $_{\mathrm{t}-1}$ & $\begin{array}{l}2.453 * * * \\
(15.35)\end{array}$ & $\begin{array}{l}2.298 * * * \\
(11.10)\end{array}$ & $\begin{array}{l}3.356 * * * \\
(12.77)\end{array}$ & & $\begin{array}{l}2.443 * * * \\
(15.33)\end{array}$ & $\begin{array}{l}2.286 * * * \\
(11.06)\end{array}$ & $\begin{array}{l}3.366^{* * * *} \\
(12.41)\end{array}$ & \\
\hline $\operatorname{lnTFP}_{\mathrm{t}-1}$ & $\begin{array}{l}-0.056 \\
(0.54)\end{array}$ & $\begin{array}{l}-0.071 \\
(0.56)\end{array}$ & $\begin{array}{l}-0.029 \\
(0.23)\end{array}$ & $\begin{array}{l}-0.210 \\
(0.85)\end{array}$ & & & & \\
\hline $\operatorname{lnLP} P_{t-1}$ & & & & & $\begin{array}{l}0.055 \\
(0.29)\end{array}$ & $\begin{array}{l}0.091 \\
(0.38)\end{array}$ & $\begin{array}{l}0.160 \\
(0.71)\end{array}$ & $\begin{array}{l}-0.456 \\
(0.85)\end{array}$ \\
\hline Size $_{t-1}$ & $\begin{array}{l}0.336 * * * \\
(5.66)\end{array}$ & $\begin{array}{l}0.453 * * * \\
(4.60)\end{array}$ & $\begin{array}{l}0.211^{* *} \\
(2.38)\end{array}$ & $\begin{array}{l}0.474 * * * \\
(3.65)\end{array}$ & $\begin{array}{l}0.325 * * * \\
(5.67)\end{array}$ & $\begin{array}{l}0.439 * * * \\
(4.64)\end{array}$ & $\begin{array}{l}0.204 * * \\
(2.38)\end{array}$ & $\begin{array}{l}0.413 * * * \\
(4.01)\end{array}$ \\
\hline Capital Intensity $\mathrm{t}_{\mathrm{t}-1}$ & $\begin{array}{l}-0.259 * * * \\
(4.10)\end{array}$ & $\begin{array}{l}-0.360 * * * \\
(3.70)\end{array}$ & $\begin{array}{l}-0.038 \\
(0.41)\end{array}$ & $\begin{array}{l}-0.601 * * * \\
(4.05)\end{array}$ & $\begin{array}{l}-0.255^{* * * *} \\
(4.02)\end{array}$ & $\begin{array}{l}-0.357 * * * \\
(3.68)\end{array}$ & $\begin{array}{l}-0.042 \\
(0.46)\end{array}$ & $\begin{array}{l}-0.525^{* * *} \\
(4.39)\end{array}$ \\
\hline $\operatorname{Age}_{t-1}$ & $\begin{array}{l}-0.054 \\
(0.39)\end{array}$ & $\begin{array}{l}-0.070 \\
(0.34)\end{array}$ & $\begin{array}{l}0.185 \\
(1.00)\end{array}$ & $\begin{array}{l}-0.113 \\
(0.40)\end{array}$ & $\begin{array}{l}-0.048 \\
(0.35)\end{array}$ & $\begin{array}{l}-0.066 \\
(0.32)\end{array}$ & $\begin{array}{l}0.192 \\
(1.04)\end{array}$ & $\begin{array}{l}-0.121 \\
(0.43)\end{array}$ \\
\hline Wage $_{t-1}$ & $\begin{array}{l}0.043 \\
(1.60)\end{array}$ & $\begin{array}{l}0.054 \\
(1.39)\end{array}$ & $\begin{array}{l}0.023 \\
(0.79)\end{array}$ & $\begin{array}{l}0.420 \\
(1.55)\end{array}$ & $\begin{array}{l}0.041 \\
(1.56)\end{array}$ & $\begin{array}{l}0.050 \\
(1.30)\end{array}$ & $\begin{array}{l}0.020 \\
(0.67)\end{array}$ & $\begin{array}{l}0.397 \\
(1.63)\end{array}$ \\
\hline Innovation $_{\mathrm{t}-1}$ & $\begin{array}{l}-0.081 \\
(0.77)\end{array}$ & $\begin{array}{l}-0.086 \\
(0.63)\end{array}$ & $\begin{array}{l}-0.126 \\
(0.89)\end{array}$ & $\begin{array}{l}0.262 \\
(1.18)\end{array}$ & $\begin{array}{l}-0.085 \\
(0.81)\end{array}$ & $\begin{array}{l}-0.090 \\
(0.65)\end{array}$ & $\begin{array}{l}-0.130 \\
(0.92)\end{array}$ & $\begin{array}{l}0.262 \\
(1.18)\end{array}$ \\
\hline Govsupport $_{\mathrm{t}-1}$ & $\begin{array}{l}-0.007 \\
(0.06)\end{array}$ & $\begin{array}{l}-0.005 \\
(0.03)\end{array}$ & $\begin{array}{l}0.034 \\
(0.23)\end{array}$ & $\begin{array}{l}-0.065 \\
(0.36)\end{array}$ & $\begin{array}{l}-0.007 \\
(0.06)\end{array}$ & $\begin{array}{l}-0.004 \\
(0.03)\end{array}$ & $\begin{array}{l}0.044 \\
(0.30)\end{array}$ & $\begin{array}{l}-0.060 \\
(0.33)\end{array}$ \\
\hline Credit constraint $_{\mathrm{t}-1}$ & $\begin{array}{l}0.300^{* *} \\
(2.04)\end{array}$ & $\begin{array}{l}0.466^{* *} \\
(2.48)\end{array}$ & $\begin{array}{l}0.583^{* *} \\
(3.20)^{*}\end{array}$ & $\begin{array}{l}1.107 * * * \\
(5.36)\end{array}$ & $\begin{array}{l}0.295 * * \\
(2.01)^{* *}\end{array}$ & $\begin{array}{l}0.459 * * \\
(2.45)^{* *}\end{array}$ & $\begin{array}{l}0.583 * * * \\
(3.17)\end{array}$ & $\begin{array}{l}1.116^{* * * *} \\
(5.37)\end{array}$ \\
\hline Relation $_{\mathrm{t}-1}$ & $\begin{array}{l}0.182 \\
(0.84)\end{array}$ & $\begin{array}{l}0.466 \\
(1.64)\end{array}$ & $\begin{array}{l}-0.039 \\
(0.13)\end{array}$ & $\begin{array}{l}4.094^{* * *} \\
(9.16)\end{array}$ & $\begin{array}{l}0.171 \\
(0.79)\end{array}$ & $\begin{array}{l}0.450 \\
(1.60)\end{array}$ & $\begin{array}{l}-0.057 \\
(0.19)\end{array}$ & $\begin{array}{l}4.113 * * * \\
(9.68)\end{array}$ \\
\hline Location & Yes & Yes & No & Yes & Yes & Yes & No & Yes \\
\hline Type & Yes & Yes & Yes & Yes & Yes & Yes & Yes & Yes \\
\hline Industry & Yes & Yes & Yes & No & Yes & Yes & Yes & No \\
\hline Year2009 & $\begin{array}{l}0.026 \\
(0.26)\end{array}$ & $\begin{array}{l}0.075 \\
(0.56)\end{array}$ & No & $\begin{array}{l}0.234 \\
(1.11)\end{array}$ & $\begin{array}{l}0.018 \\
(0.17)\end{array}$ & $\begin{array}{l}0.063 \\
(0.47)\end{array}$ & No & $\begin{array}{l}0.232 \\
(1.09)\end{array}$ \\
\hline Constant & $\begin{array}{l}-4.021^{* * * *} \\
(2.73)\end{array}$ & $\begin{array}{l}-5.484^{* * *} \\
(2.88)\end{array}$ & $\begin{array}{l}-5.709^{* * *} \\
(3.12)\end{array}$ & $\begin{array}{l}-13.239^{* * *} \\
(4.99)\end{array}$ & $\begin{array}{l}-5.263 * * \\
(2.24)\end{array}$ & $\begin{array}{l}-7.262 * * \\
(2.41)\end{array}$ & $\begin{array}{l}-7.884 * * * \\
(2.77)\end{array}$ & $\begin{array}{l}-9.843^{*} \\
(1.77)\end{array}$ \\
\hline Observations & 4077 & 4077 & 4077 & 3783 & 4077 & 4077 & 4077 & 3783 \\
\hline Pseudo R2 & 0.62 & & & 0.80 & 0.61 & & & 0.80 \\
\hline Log Likelihood & & -379.85 & -373.82 & & & -379.93 & -373.07 & \\
\hline
\end{tabular}

Note: Robust $z$ statistics in parentheses; * significant at 10\%; ** significant at $5 \% ; * * *$ significant at $1 \%$.

The insignificant estimated coefficients of the past productivity, which is measured by both TFP and labor productivity, indicate that decision to export of the SMEs is not affected by their past productivity. Thus, exporting SMEs were not necessarily more productive than their non-exporting counterparts ex ante joining the foreign markets. In addition, past innovation does not show any significant effects on the decision to export of the SMEs. The coefficients for the past export experience are significantly positive at $1 \%$ level of confidence, which is similar to what was found in the previous studies (Arnold \& Hussinger 2005; Ranjan \& Raychoudhuri 2011). This finding implies that sunk entry costs play a crucial role in determining export of the SMEs. In the context of a transition economy like Vietnam, many obstacles have hindered the SMEs from exporting. The SMEs have been granted full rights to export since not long ago. They lack of human resources, knowledge of international trade laws, customs, language, finance, and foreign market information. Costs for the SMEs to overcome these cross border barriers are high. Additionally, the results show that firm size has positive and highly significant effects on the decision to export of the SMEs. Moreover, capital intensity has negative and highly significant effects on the decision to export of the SMEs. These observations are in line with the results that wage has no effect on export of the SMEs. These findings suggest that Hypothesis H1 is not supported when conventional indicators of firm performance, which are productivity and innovation, are used in analyzing the 
self-selection hypothesis. Nevertheless, Hypothesis H1 is supported when sunk costs, firm size, and capital intensity are used. These facts are in line with characteristics of the SME exporters in a transition economy like Vietnam, where most of them are in labor-intensive industries and taking part in simple mass production requiring little innovation and increased productivity for exporting. These SMEs' sources of competitiveness mainly come from low-cost labor instead.

\subsection{Learning-by-exporting estimation results}

Table 3 presents the effects of entering export markets on performance of the SMEs. In this table, SME performance is measured by various indicators, which are TFP, labor productivity, sales revenue, value added, firm size proxied by total value of physical capital, employment, and average wage. The estimation results provide evidence to support the learning-by-exporting hypothesis as almost all of the performance indicators have positive and statistically significant coefficients. On average, the SMEs had from 16.4 to 19.9 percentage points higher in TFP as they became exporters. Similarly, labor productivity of the SMEs increased by 25 percentage points after joining export markets. The estimation results also show that exporting has increased sales revenue, value added, firm size, wage, and employment.

Table 3

Effects of exporting on firm performance

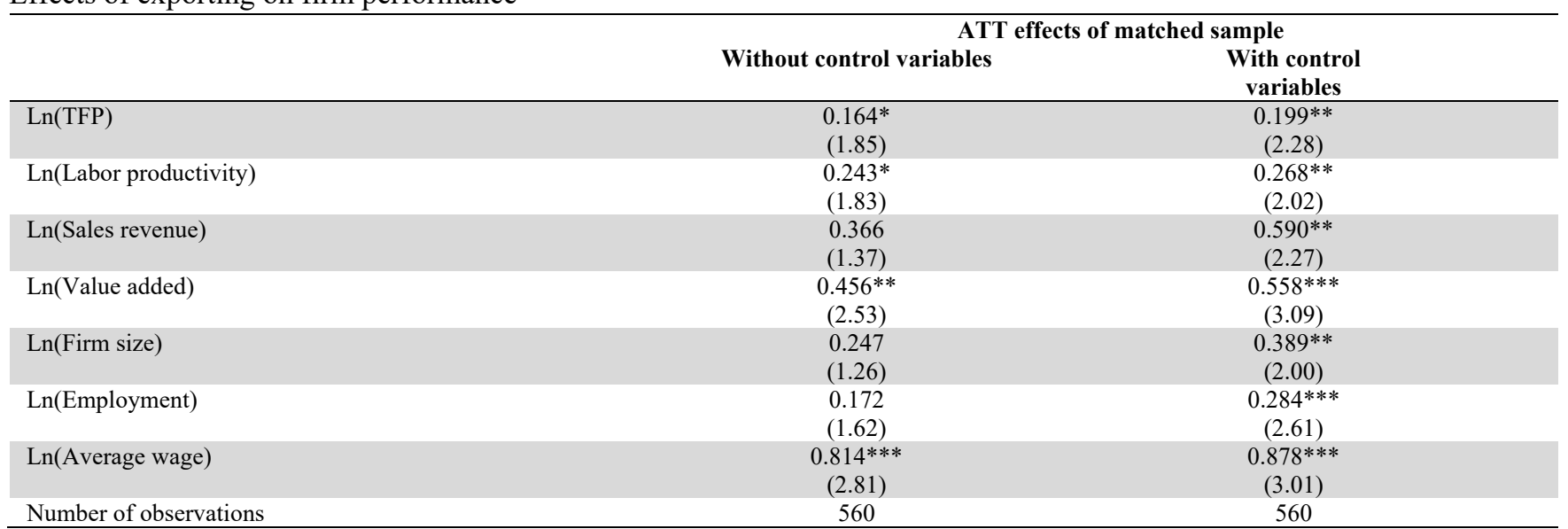

Note: Absolute value of $z$ statistics in parentheses; * significant at $10 \% ; * *$ significant at $5 \%$; *** significant at $1 \%$.

To see how these learning-by-exporting effects change over time, we followed De Loecker (2007) and Pisu (2008) to estimate both level and growth rates of the SMEs' performance indicators. From Table 4 we can see that the learning-by-exporting effects are strong right after entering the export markets and two years after being exporters. These effects, however, decline when the SMEs stay in exporting markets for more than 4 years. These findings recall the idea of "learning-by-doing" of Arrow (1971), who mentions that learning is a product of experience and learning can only occur with an attempt to solve problems. According to Arrow (1971), learning-by-doing by its nature brings about benefits but these benefits might diminish over time if the situation itself is repeated rather than stimulus. That might explain for the short-time learning effects of exporting on productivity and suggest a solution to prolong the benefits overtime (Martins \& Yang 2009; Alvarez \& Lopez 2005).

\section{Table 4}

Year- to- year learning-by-exporting effects

\begin{tabular}{|c|c|c|c|c|c|c|c|}
\hline \multicolumn{4}{|c|}{ Right after } & \multicolumn{4}{|c|}{2 years later } \\
\hline \multicolumn{2}{|c|}{ Level effect } & \multicolumn{2}{|c|}{ Growth effect } & \multicolumn{2}{|c|}{ Level effect } & \multicolumn{2}{|c|}{ Growth effect } \\
\hline No control & With Control & No Control & With Control & No control & With Control & No Control & $\begin{array}{c}\text { With } \\
\text { Control }\end{array}$ \\
\hline $0.273 * *$ & $\begin{array}{l}0.169 \\
(148)\end{array}$ & $0.212^{*}$ & 0.137 & $0.256^{* *}$ & $0.214^{*}$ & $\begin{array}{l}0.236 \\
(159)\end{array}$ & $0.317 * *$ \\
\hline$(2.43)$ & (1.48) & $(1.82)$ & (1.11) & $(2.13)$ & (1.96) & (1.59) & $(2.12)$ \\
\hline $0.489 * *$ & $0.340^{*}$ & $0.398 *$ & 0.272 & $0.316^{*}$ & 0.233 & 0.202 & 0.204 \\
\hline (2.09) & $(1.95)$ & $(1.71)$ & (1.33) & (1.91) & $(1.50)$ & $(1.00)$ & $(0.85)$ \\
\hline $1.350 * * *$ & $0.826^{* *}$ & 0.655 & 0.273 & 0.790 ** & $0.648^{* *}$ & 0.042 & 0.109 \\
\hline (2.77) & $(2.38)$ & (1.48) & $(0.85)$ & $(2.48)$ & $(2.56)$ & $(0.17)$ & $(0.37)$ \\
\hline $0.785^{* * *}$ & $0.543 * *$ & $0.497 *$ & $0.543 * *$ & $0.942 * * *$ & $0.904 * * *$ & 0.327 & $0.531^{*}$ \\
\hline$(2.70)$ & $(2.50)$ & (1.70) & $(2.20)$ & $(3.22)$ & (3.98) & (1.31) & (1.78) \\
\hline $1.283 * * *$ & $1.266^{* * *}$ & $0.742 * *$ & $0.841^{* *}$ & $1.380^{* *}$ & $1.327^{* *}$ & 0.591 & 0.440 \\
\hline$(3.25)$ & $(2.75)$ & $(2.60)$ & (2.19) & $(2.63)$ & $(2.23)$ & (1.36) & $(0.84)$ \\
\hline $0.538 * * *$ & $0.473 * * *$ & 0.130 & $0.270^{*}$ & $0.626^{* * *}$ & $0.671 * * *$ & 0.127 & 0.328 \\
\hline$(2.91)$ & (3.18) & (1.08) & (1.91) & (2.83) & (3.78) & $(0.71)$ & (1.65) \\
\hline 0.364 & 0.278 & -0.047 & 0.027 & $0.691 * *$ & $0.735^{* *}$ & 0.409 & 0.498 \\
\hline (1.52) & (1.27) & $(0.23)$ & $(0.11)$ & $(2.02)$ & (2.11) & (1.36) & (1.48) \\
\hline
\end{tabular}

Note: Absolute value of $z$ statistics in parentheses; * significant at $10 \% ; * *$ significant at $5 \%$; *** significant at $1 \%$. 
These findings provide evidence of the learning-by-exporting effects among the Vietnam SMEs, thus, supporting Hypothesis H2. These SMEs have become more productive, expanded their size, produced more outputs and paid higher wages after joining the export markets. These findings indicate gains of being exporters for the Vietnamese SMEs. This study went further in analyzing the trajectory of effects over time and showed that learning effects are stronger in the early years of being exporters and lower in the long run. These findings provide empirical evidence for policymakers to design export promotion policies.

Table 4 (continued)

Year- to- year learning-by-exporting effects

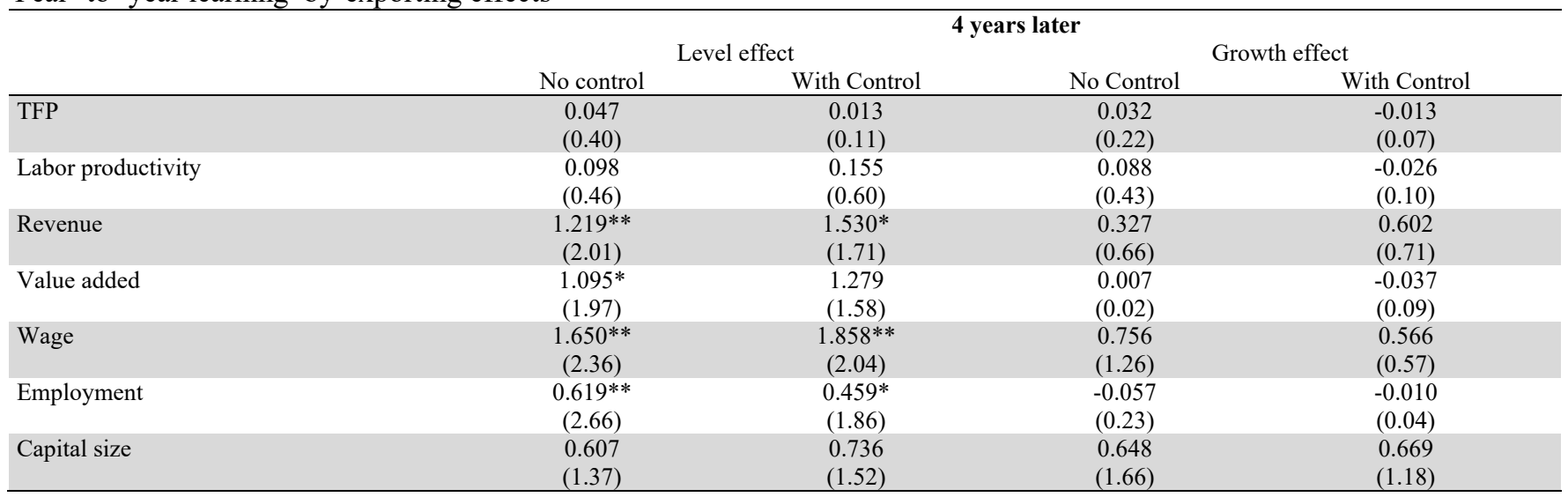

Note: Absolute value of z statistics in parentheses; * significant at 10\%; ** significant at $5 \%$; *** significant at $1 \%$.

\subsection{Core competence estimation results}

In Table 5, the estimated coefficients for the interaction term between being treated and starting to export are negative and highly significant. This finding reflects a robust result that exporting causes SMEs' capital intensity to decrease. The decrease in capital intensity implies a resource reallocation within firms towards more labor-intensive products after exporting. This observation provides empirical evidence for the existence of core-competence effects within the Vietnam SMEs. Thus, Hypothesis H3 is supported. This evidence is along with an expectation that Vietnamese exporters would specialize in their core-competence of labor-intensive products after joining exporting markets. In combination with the previous findings, the SMEs with lower capital intensity self-select into export markets. After being exporters, they continue to concentrate on their core-competence. The bi-dimensional relationship of exporting and factor intensity suggests policies to enhance participation in and effectiveness of export of the SMEs.

Table 5

Capital intensity

\begin{tabular}{|c|c|c|c|c|}
\hline & $\begin{array}{c}(1) \\
\text { OLS } \\
\text { no control }\end{array}$ & $\begin{array}{c}\text { (2) } \\
\text { OLS } \\
\text { With control }\end{array}$ & $\begin{array}{c}\text { (3) } \\
\text { Random Effect } \\
\text { no control }\end{array}$ & $\begin{array}{c}\text { (4) } \\
\text { Random Effect } \\
\text { With control }\end{array}$ \\
\hline Treatment & $\begin{array}{c}-0.028 \\
(0.18)\end{array}$ & $\begin{array}{l}-0.159 \\
(1.59)\end{array}$ & $\begin{array}{l}-0.091 \\
(0.46)\end{array}$ & $\begin{array}{l}-0.215 \\
(1.82)\end{array}$ \\
\hline Post & $\begin{array}{l}0.097 \\
(0.59)\end{array}$ & $\begin{array}{l}0.215 \\
(1.74)\end{array}$ & $\begin{array}{l}0.102 \\
(0.74)\end{array}$ & $\begin{array}{c}0.280 \\
(3.75)^{* * *}\end{array}$ \\
\hline Treatment*post & $\begin{array}{l}-0.080 \\
(0.35)\end{array}$ & $\begin{array}{c}-0.353 * * * \\
(2.75)\end{array}$ & $\begin{array}{l}0.035 \\
(0.18)\end{array}$ & $\begin{array}{c}-0.221 * * \\
(2.10)\end{array}$ \\
\hline Industry dummies & & Yes & & Yes \\
\hline Ownership dummies & & Yes & & Yes \\
\hline Year dummies & & Yes & & Yes \\
\hline Firm size & & $\begin{array}{c}0.770 * * * \\
(29.85)\end{array}$ & & $\begin{array}{c}0.810 * * * \\
(33.39)\end{array}$ \\
\hline Constant & $\begin{array}{c}12.249 * * * \\
(117.01)\end{array}$ & $\begin{array}{l}0.419 \\
(1.03)\end{array}$ & $\begin{array}{c}12.246 * * * \\
(87.17)\end{array}$ & $\begin{array}{l}0.111 \\
(0.22)\end{array}$ \\
\hline No. of observations & 496 & 496 & 496 & 496 \\
\hline
\end{tabular}

Note: Absolute value of $z$ statistics in parentheses; * significant at $10 \%$; ** significant at $5 \%$; *** significant at $1 \%$.

\section{Conclusion}

This study has utilized biennial longitudinal data on Vietnam small- and medium- sized enterprises (SMEs) from surveys conducted from 2007 to 2013. The study has found evidence to support the self-selection hypothesis with non-conventional indicators of firm performance, which are sunk costs, firm size, and capital intensity. The evidence of Vietnam SMEs' self- 
selecting into the exporting markets are mixed. Prior to entering the export markets, would-be SME exporters were bigger in capital size, but not necessarily more productive. Entry cost or past export experience is the most important determinant for the decision to export of the Vietnamese SMEs. Labor-intensive SMEs have higher probability to become exporters. These findings suggest that policymakers should consider policies that reduce sunk costs and pay more attention to labor-intensive industries in order to raise the number of exporters among Vietnamese SMEs. In addition, the study finds that higher performance of the SME exporters comes from exporting in foreign markets as there exists statistically significant evidence of the learning-byexporting and core-competence effects. The SMEs have benefited from exporting because it helps increase firm productivity, sales revenue, value added, firm size, and average wages. The study further contributes to the literature by pointing out that the improvement of the SMEs' performance was higher during the early years and declined afterward. These findings help policymakers identify appropriate timing when their policies should come in place to maximize gains from exporting for the SMEs in a transition economy. Another contribution of this study to the literature is to provide empirical evidence of the positive relationship between exporting and labor intensity among Vietnamese SMEs. Labor intensive SMEs self-select to become exporters. Exporting causes the SMEs to reallocate their resources towards their core-competence, which are in labor-intensive products. Participation of the SMEs in exporting has not yet increased Vietnamese SMEs' capital intensity. Instead, the focus of the SMEs has been still on labor-intensive industries, of which the competitive advantages come from labor abundance and lowwages in transition economies like Vietnam.

\section{Acknowledgements}

This research is funded by Vietnam National Foundation for Science and Technology Development (NAFOSTED) under grant number 502.01-2018.03.

\section{References}

Alegre, J., \& Chiva, R. (2008). Assessing the impact of organizational learning capability on product innovation performance: An empirical test. Technovation, 28(6), 315-326.

Alvarez, R., \& Lopez, R. A. (2005). Exporting and performance: evidence from Chilean plants. Canadian Journal of Economics/Revue canadienne d'économique, 38(4), 1384-1400.

Arnold, J. M., \& Hussinger, K. (2005). Export behavior and firm productivity in German manufacturing: A firm-level analysis. Review of World Economics, 141(2), 219-243.

Arrow, K. J. (1971). The economic implications of learning by doing. In Readings in the Theory of Growth (pp. 131-149). Palgrave Macmillan, London.

Aw, B. Y., Chen, X., \& Roberts, M. J. (2001). Firm-level evidence on productivity differentials and turnover in Taiwanese manufacturing. Journal of Development Economics, 66(1), 51-86.

Baldwin, J. R., \& Gu, W. (2003). Export-market participation and productivity performance in Canadian manufacturing. Canadian Journal of Economics/Revue canadienne d'économique, 36(3), 634-657.

Baldwin, R. (1988). Hysteresis in import prices: the beachhead effect (No. w2545). National Bureau of Economic Research.

Baldwin, R., \& Krugman, P. (1989). Persistent trade effects of large exchange rate shocks. The Quarterly Journal of Economics, 104(4), 635-654.

Becker, S. O., \& Ichino, A. (2002). Estimation of average treatment effects based on propensity scores. The Stata Journal, 2(4), 358-377.

Bernard, A. B., Jensen, J. B., \& Lawrence, R. Z. (1995). Exporters, jobs, and wages in US manufacturing: 1976-1987. Brookings papers on economic activity. Microeconomics, 1995, 67-119.

Bernard, A. B., \& Jensen, J. B. (1999). Exceptional exporter performance: cause, effect, or both?. Journal of international economics, 47(1), 1-25.

Bernard, A. B., \& Jensen, J. B. (2004). Why some firms export. Review of economics and Statistics, 86(2), $561-569$.

Bernard, A. B., \& Jensen, J. B. (2004). Exporting and Productivity in the USA. Oxford Review of Economic Policy, 20(3), 343357.

Bernard, A. B., Redding, S. J., \& Schott, P. K. (2011). Multiproduct firms and trade liberalization. The Quarterly journal of economics, 126(3), 1271-1318.

Castellani, D. (2002). Export behavior and productivity growth: Evidence from Italian manufacturing firms. Weltwirtschaftliches Archiv, 138(4), 605-628.

Clerides, S. K., Lach, S., \& Tybout, J. R. (1998). Is learning by exporting important? Micro-dynamic evidence from Colombia, Mexico, and Morocco. The quarterly journal of economics, 113(3), 903-947.

Doan, N. T., Nguyen, K. T., \& Mai, P. C. (2020). The effects of cash in advance on export decision: the case of Vietnam. Journal of International Economics and Management, 20(1), 1-12.

De Loecker, J. (2007). Do exports generate higher productivity? Evidence from Slovenia. Journal of international economics, 73(1), 69-98. 
Delgado, M. A., Farinas, J. C., \& Ruano, S. (2002). Firm productivity and export markets: a non-parametric approach. Journal of international Economics, 57(2), 397-422.

Dixit, A. (1989). Hysteresis, import penetration, and exchange rate pass-through. The Quarterly Journal of Economics, 104(2), 205-228.

Eckel, C., \& Neary, J. P. (2010). Multi-product firms and flexible manufacturing in the global economy. The Review of Economic Studies, 77(1), 188-217.

Feenstra, R., \& Ma, H. (2007). Optimal choice of product scope for multiproduct firms under monopolistic competition (No. w13703). National Bureau of Economic Research.

Feenstra, R. C., Li, Z., \& Yu, M. (2014). Exports and credit constraints under incomplete information: Theory and evidence from China. Review of Economics and Statistics, 96(4), 729-744.

Feng, D., Chen, Q., Song, M., \& Cui, L. (2019). Relationship between the degree of internationalization and performance in manufacturing enterprises of the Yangtze river delta region. Emerging Markets Finance and Trade, 55(7), $1455-1471$.

Fernandes, A. M., \& Isgut, A. E. (2015). Learning-by-exporting effects: are they for real?. Emerging Markets Finance and Trade, 51(1), 65-89.

Filipescu, D. A., Rialp, A., \& Rialp, J. (2009). Internationalisation and technological innovation: empirical evidence on their mutual relationship. Advances in International Marketing, 20, 125-154.

Fornes, G., \& Cardoza, G. (2019). Internationalization of Chinese SMEs: The perception of disadvantages of foreignness. Emerging Markets Finance and Trade, 55(9), 2086-2105.

General Statistics Office (2017). Vietnam's Exports and Imports of Goods- International Integration and Development. Hanoi: Statistical Publishing House.

Girma, S., Greenaway, A., \& Kneller, R. (2004). Does exporting increase productivity? A microeconometric analysis of matched firms. Review of International Economics, 12(5), 855-866.

Greenaway, D., \& Kneller, R. (2004). Exporting and productivity in the United Kingdom. Oxford Review of Economic Policy, 20(3), 358-371.

Greenaway, D., Gullstrand, J., \& Kneller, R. (2005). Exporting may not always boost firm productivity. Review of World Economics, 141(4), 561-582.

Heckman, J. J. (1981). Heterogeneity and state dependence. In Studies in labor markets (pp. 91-140). University of Chicago Press.

Hitt, M. A., Hoskisson, R. E., \& Kim, H. (1997). International diversification: Effects on innovation and firm performance in product-diversified firms. Academy of Management journal, 40(4), 767-798.

Kafouros, M. I., Buckley, P. J., Sharp, J. A., \& Wang, C. (2008). The role of internationalization in explaining innovation performance. Technovation, 28(1-2), 63-74.

Kimura, F., \& Kiyota, K. (2006). Exports, FDI, and productivity: Dynamic evidence from Japanese firms. Review of World Economics, 142(4), 695-719.

Krugman, P. R. (1979). Increasing returns, monopolistic competition, and international trade. Journal of International Economics, 9(4), 469-479.

Leonidou, L. C., Katsikeas, C. S., Palihawadana, D., \& Spyropoulou, S. (2007). An analytical review of the factors stimulating smaller firms to export. International Marketing Review.

Leuven, E., \& Sianesi, B. (2018). PSMATCH2: Stata module to perform full Mahalanobis and propensity score matching, common support graphing, and covariate imbalance testing.

Levinsohn, J., \& Petrin, A. (2003). Estimating production functions using inputs to control for unobservables. The review of economic studies, 70(2), 317-341.

Ma, Y., Tang, H., \& Zhang, Y. (2014). Factor intensity, product switching, and productivity: Evidence from Chinese exporters. Journal of International Economics, 92(2), 349-362.

Martins, P. S., \& Yang, Y. (2009). The impact of exporting on firm productivity: a meta-analysis of the learning-by-exporting hypothesis. Review of World Economics, 145(3), 431-445.

Melitz, M. J. (2003). The impact of trade on intra-industry reallocations and aggregate industry productivity. Econometrica, 71(6), 1695-1725.

Minetti, R., \& Zhu, S. C. (2011). Credit constraints and firm export: Microeconomic evidence from Italy. Journal of International Economics, 83(2), 109-125.

Ministry of Investment and Planning (2016). Annual report on enterprises and socio-economic development in 2014-2015. Hanoi: Ministry of Investment and Planning.

Monreal-Pérez, J., Aragón-Sánchez, A., \& Sánchez-Marín, G. (2012). A longitudinal study of the relationship between export activity and innovation in the Spanish firm: The moderating role of productivity. International Business Review, 21(5), 862877.

Nguyen, A. N., Pham, N. Q., Nguyen, C. D., \& Nguyen, N. D. (2008). Innovation and exports in Vietnam's SME sector. The European Journal of Development Research, 20(2), 262-280. 
Pär, H., \& Nan, L. N. (2004). Exports as an Indicator on or Promoter of Successful Swedish Manufacturing Firms in the 1990s. Review of World Economics, 140(3), 415-445.

Park, A., Yang, D., Shi, X., \& Jiang, Y. (2010). Exporting and firm performance: Chinese exporters and the Asian financial crisis. The Review of Economics and Statistics, 92(4), 822-842.

Park, B. I. (2011). Knowledge transfer capacity of multinational enterprises and technology acquisition in international joint ventures. International Business Review, 20(1), 75-87.

Pisu, M. (2008). Export destinations and learning-by-exporting: Evidence from Belgium. National Bank of Belgium working paper, (140).

Pla-Barber, J., \& Alegre, J. (2007). Analysing the link between export intensity, innovation and firm size in a science-based industry. International Business Review, 16(3), 275-293.

Ranjan, P., \& Raychaudhuri, J. (2011). Self-selection vs learning: evidence from Indian exporting firms. Indian Growth and Development Review, 4(1), 22-37.

Roberts, M. J., \& Tybout, J. R. (1997). The decision to export in Colombia: An empirical model of entry with sunk costs. The American Economic Review, 545-564.

Rosenbaum, P. R., \& Rubin, D. B. (1983). The central role of the propensity score in observational studies for causal effects. Biometrika, 70(1), 41-55.

Silva, A., Afonso, Ó., \& Africano, A. P. (2010). Do Portuguese manufacturing firms learn by exporting? (No. 373). Universidade do Porto, Faculdade de Economia do Porto.

Tomiura, E. (2007). Foreign outsourcing, exporting, and FDI: A productivity comparison at the firm level. Journal of International Economics, 72(1), 113-127.

VCCI. 2017. Annual Report on Vietnamese Business 2016. Hanoi: Information and Communications Publishing House.

Vu, H., Lim, S., Holmes, M., \& Doan, T. (2013). Firm Exporting and Employee Benefits: First Evidence from Vietnam Manufacturing SMEs. Economics Bulletin, 33(1), 519-535.

Vu, H. N., \& Hoang, B. T. (2020). Business environment and innovation persistence: the case of small-and medium-sized enterprises in Vietnam. Economics of Innovation and New Technology, https://doi.org/10.1080/10438599.2019.1689597

Wagner, J. (2007). Exports and productivity: A survey of the evidence from firm-level data. World Economy, 30(1), 60-82.

Wagner, J. (2012). International trade and firm performance: a survey of empirical studies since 2006. Review of World Economics, 148(2), 235-267.

Wernerfelt, B. (1984). A resource-based view of the firm. Strategic Management Journal, 5(2), 171-180.

World Bank (2019). The Wold Bank. Retrieved 06 01, 2017, from data.worldbank.org: https://data.worldbank.org/indicator/NY.GDP.DEFL.ZS?locations $=$ VN

\section{Appendix A}

Bernard and Jensen $(1995,1999,2004)$ started with a simple case with one time period and no entry cost, the profit function $\Pi_{i t}$ of firm $i$ at time period $t$ is as below:

$$
\Pi_{\text {it }}\left(X_{t}, Z_{i t}\right)=p_{t} \cdot q_{i t}^{*}-c_{i t}\left(X_{t}, Z_{i t} \mid q_{i t}^{*}\right)
$$

where $\mathrm{q}_{\mathrm{it}}{ }^{*}$ is the optimal quantity produced if a firm exports; $\mathrm{c}_{\mathrm{it}}$ is the cost of producing quantity $\mathrm{q}_{\mathrm{it}}{ }^{*}$; $\mathrm{p}_{\mathrm{t}}$ is the selling price of goods in the foreign market; $X_{\mathrm{t}}$ is the vector of exogenous factors that affect production of the firm such as exchange rate, export promotion regimes; $Z_{\text {it }}$ is a vector of all endogenous or firm-specific factors that have influence on profitability such as productivity, size, age, labor quality, innovation. If an expected profit of exporting is equal to or greater than zero, a firm will export. Otherwise, it remains serving the domestic market only. Denoting Yit as firm i's export status at time $t$, then Yit $=1$ if $\Pi$ it $\geq 0$ and $Y$ it $=0$ if $\Pi i t<0$. In the multiple periods case, let $\delta$ represent a single discounting rate, then expected profit of a firm becomes:

$$
\Pi_{\mathrm{it}}\left(\mathrm{X}_{\mathrm{t}}, \mathrm{Z}_{\mathrm{it}}\right)=\mathrm{E}_{\mathrm{t}}\left(\sum_{s=t}^{\infty} \delta^{s-t} \cdot\left[p_{s} \cdot q_{i s}^{*}-c_{i s} \cdot\left(X_{s}, Z_{i s} \mid q_{i s}^{*}\right)\right]\right)
$$

As long as the cost function of today production does not depend on production in previous periods, then the expected profit function in the multi-period case is similar to the single period case. Otherwise, the current export status will have effects on future export status and the value function of the optimizing problem is as follow:

$$
V_{i t}(.)=\max _{\left\{q_{i t}^{*}\right\}}\left(\pi_{\mathrm{it}} . \mathrm{Y}_{\mathrm{it}}+\delta . \mathrm{E}_{\mathrm{t}}\left[\mathrm{V}_{\mathrm{it}+1}(.) \mid \mathrm{q}^{*} \mathrm{it}\right]\right)
$$

A firm will export in period $t$ if the following inequality satisfies:

$$
\Pi_{i t}+\delta . E_{t}\left[V_{i t+1}(.) \mid q^{*}{ }_{i t}>0\right]>\delta . E_{t}\left[V_{i t+1}(.) \mid q^{*}{ }_{i t}=0\right]
$$


Entry costs are denoted by N. It is normal to make an assumption that firm will not have to pay entry costs if they had already exported (i.e. $\mathrm{N}=0$ if $\mathrm{Yit}-1=1$ ). When making a decision to export, firms understand that if they export today, they might not have to pay entry costs in the future. In a single-period case with entry costs, a firm's profit is specified as follows:

$\Pi_{i t}^{\prime}\left(X_{t}, Z_{i t,} q_{i t-1}^{*}\right)=p_{t} \cdot q_{i t}^{*}-c_{i t}\left(X_{t}, Z_{i t}, q_{i t-1}^{*} \mid q_{i t}^{*}\right)-N\left(1-Y_{i t-1}\right)$

This means firms do not have to pay entry cost if they exported in the previous periods, i.e. Yit-1=1. Firms will export if expected profits minus entry costs are positive. It means $Y i t=1$ if $\Pi_{i t}^{\prime}>0$. In a multi-period case with entry costs, firms choose a sequence of output levels, $\left\{q_{i t}^{*}\right\}_{s=t}^{\infty}$, that maximizes current and discounted future profit. It means $\Pi_{\mathrm{it}}=\mathrm{E}_{\mathrm{t}}\left(\sum_{s=t}^{\infty} \delta^{s-\mathrm{t}}\left[\Pi_{i s}^{\prime} . \mathrm{Y}_{\mathrm{is}}\right]\right)$, where in the single-period $\Pi_{i s}^{\prime}$ is non-negative as firms have an option of not exporting. With a value function as represented below:

$$
V_{i t}(.)=\max _{\left\{q_{i t}^{*}\right\}}\left(\Pi_{i t}^{\prime} \cdot\left[\mathrm{q}^{*}{ }_{\mathrm{it}}>0\right]+\delta . \mathrm{E}_{\mathrm{t}}\left[\mathrm{V}_{\mathrm{it}+1}(.) \mid \mathrm{q}^{*} \mathrm{it}\right]\right)
$$

Firm $i$ will export in time $t$ if expected profit net any entry costs is greater than zero as follows:

$$
\mathrm{p}_{\mathrm{t}} \cdot \mathrm{q}_{\mathrm{it}}{ }^{*}+\delta .\left(\mathrm{E}_{\mathrm{t}}\left[\mathrm{V}_{\mathrm{it}+1}(.) \mid \mathrm{q}_{\mathrm{it}}^{*}>0\right]-\mathrm{E}_{\mathrm{t}}\left[\mathrm{V}_{\mathrm{it}+1}(.) \mid \mathrm{q}_{\mathrm{it}}^{*}=0\right]\right)-\mathrm{c}_{\mathrm{it}}\left(\mathrm{X}_{\mathrm{t}}, \mathrm{Z}_{\mathrm{it},} \mathrm{q}^{*}{ }_{\mathrm{it}-1} \mid \mathrm{q}_{\mathrm{it}}{ }^{*}\right)-\mathrm{N}\left(1-\mathrm{Y}_{\mathrm{it}-1}\right)>0
$$

Or

$$
\mathrm{p}_{\mathrm{t}} \cdot \mathrm{q}_{\mathrm{it}}{ }^{*}+\delta .\left(\mathrm{E}_{\mathrm{t}}\left[\mathrm{V}_{\mathrm{it}+1}(.) \mid \mathrm{q}_{\mathrm{it}}^{*}>0\right]-\mathrm{E}_{\mathrm{t}}\left[\mathrm{V}_{\mathrm{it}+1}(.) \mid \mathrm{q}_{\mathrm{it}}^{*}=0\right]\right)>\mathrm{c}_{\mathrm{it}}\left(\mathrm{X}_{\mathrm{t}}, \mathrm{Z}_{\mathrm{it},} \mathrm{q}_{\mathrm{it}-1 \mid}^{*} \mathrm{q}_{\mathrm{it}}{ }^{*}\right)+\mathrm{N}\left(1-\mathrm{Y}_{\mathrm{it}-1}\right)
$$

If we define $\Pi_{i t}^{*}=\mathrm{pt} . \mathrm{qit}^{*}+\delta$. (Et[Vit+1 (.) $\left.\left.\mid \mathrm{q}^{*} \mathrm{it}>0\right]-\mathrm{Et}[\mathrm{Vit}+1() \mid. \mathrm{q} * \mathrm{it}=0]\right)$, the decision to export by firm is given by the following discrete choice equation:

$$
Y_{i t}=\left\{\begin{array}{cc}
1 & \text { if } \Pi_{i t}^{*}-c_{i t}-N\left(1-Y_{i t-1}\right)>0 \\
0 & \text { otherwise }
\end{array}\right.
$$

According to Roberts and Tybout (1997), a method of non-structural binary choice can be used to estimate the decision to export with the following empirical model:

$$
Y_{i t}=\left\{\begin{array}{lr}
1 \text { if } \beta X_{i t}+\gamma Z_{i t}-N\left(1-Y_{i t-1}\right)+\varepsilon_{i t}>0 \\
0 & \text { otherwise }
\end{array}\right.
$$

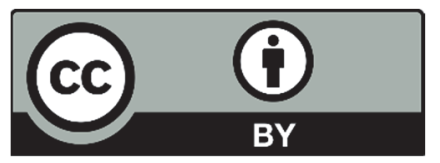

(C) 2020 by the authors; licensee Growing Science, Canada. This is an open access article distributed under the terms and conditions of the Creative Commons Attribution (CC-BY) license (http://creativecommons.org/licenses/by/4.0/). 